\title{
The Relationship of Ethics Codes, Competencies, and Professional Skeptism on the Implementation of Governtment Internal Control System
}

\author{
Slamet Widodo ${ }^{1}$, Akram Harmoni Wiardi $^{2}$, Engga Putrawan ${ }^{3}$ \\ Faculty of Economics and Business - Universitas Bengkulu ${ }^{1,2,3}$ \\ \{ slamet.widodo@gmail.com \}
}

\begin{abstract}
The objective of this study was to prove the effect of the utilization of Local Management Information System (referred as SIMDA in Indonesian terminology), the implementation of government accounting standard and government internal control system on the quality of financial report of Local Official Organization at Rejang Lebong Regency. The data used in this study was primary data obtained from the distribution of questionnaires to the financial managers of Local Official Organization at Rejang Lebong Regency. The number of samples used in this study was 164 people. However, from the result of the distribution of questionnaires, it was found that the number of samples that was feasible to be analyzed was only 142 people. The method of data analysis used was descriptive analysis and multiple regression analysis. The obtained results of the study were: (1) the utilization of SIMDA had significant effect on the quality of local financial report; (2) the implementation of government accounting standard had significant effect on the quality of local financial report; and (3) government internal control system showed significant effect on the quality of local financial report.
\end{abstract}

Keywords: The Utilization of SIMDA; The Implementation of Government Accounting Standard; Government Internal Control System; The Quality of Financial Report

\section{Introduction}

The public demand for a government that is clean and free from corruption, collusion and nepotism $(\mathrm{KKN})$ calls for the implementation of a supervisory function and a good internal control system for the implementation of government and the management of State finances. Guidelines that can provide assurance that the implementation of activities is in accordance with the policies and plans that have been set and to ensure that the objectives are achieved in an efficient, efficient and effective manner.

The role of auditors in overseeing budget execution is very important. One form of supervision whose role is very important is internal government supervision. Through internal control, it can be seen whether a government agency has carried out activities in accordance with its duties and functions effectively and efficiently, and in accordance with the stipulated 
plans, policies and regulations. In addition, internal supervision of government administration is needed to encourage the realization of good governance and clean government and to support effective, efficient, transparent, accountable and clean governance and free from practices of corruption, collusion and nepotism [1].

Basically, the duties and roles of internal auditors, such as auditors at the Inspectorate Office, are to prevent fraud. Fraud is a form of fraud committed deliberately by someone which causes losses to the party who is injured without realizing it and the fraud benefits that person. According to [2] fraud (fraud) occurs because of pressure to abuse or the urge to take advantage of existing opportunities / opportunities.

In the field of financial management, fraud means deliberate misuse by unscrupulous financial reporting entities that are detrimental to the state. A work system that is not transparent (open) in an organization is an opportunity for perpetrators of fraud. A work system that is not transparent closes the opportunity for many parties to supervise and provide input to the ongoing system [3] Usually the perpetrators of fraud will use this non-transparent work system as a medium for committing fraud. This is because someone who commits fraud is an "insider" or involves someone who has authority over the work system in the organization.

Regarding the role and function of auditors at the Inspectorate Office, currently it is still in the spotlight. Even though they have been supervised and supervised by auditors at the Inspectorate Office, in some OPDs there are still BPK findings related to OPD financial reports. Information from the BPK regarding this matter, the Inspectorate is still too lax in conducting audits so that it provides room for fraud in implementing government budget use activities. Auditors should professionally use their skills to balance suspicion and trust [4].

In the Cognitive Dissonance theory, it is stated that the presence of dissonance will cause psychological discomfort, this will motivate a person to reduce the dissonance and achieve consonance. Dissonance is an inconsistency and feeling of dislike that drives action to get out of discomfort. Cognitive dissonance occurs when the auditor has high confidence in the object of the examination (obrik), which causes his skepticism to be at a low level. In fact, an auditor must be skeptical (consonant).

The code of ethics is a series of rules regarding the behavior of moral values and norms, therefore the code of ethics covers the entire ethics of the auditors of the inspectorate clearly. However, in reality there are several auditors who do not fully comply with the code of ethics. The allocation of short audit time, auditee conditions (colleagues, friends, family), fees from auditors and pressure from superiors sometimes lowered the professional skepticism of the Bengkulu inspectorate auditors. On the other hand, it is possible that the low professional skepticism of auditors can also be caused by the unclear rules of norms and code of ethics that provide opportunities for auditors to ignore the code of ethics.

In addition to the code of ethics, the competence of auditors also determines efforts to prevent fraud. According to [5], there are three elements to prevent fraud, one of which is by implementing a culture of honesty and high ethics. The most effective way to prevent and deter fraud is to implement an anti-fraud program and controls, which are based on the core values of the organization. Such values create an environment that supports acceptable behavior and expectations, that employees can use those values to direct their actions. These values help to create a culture of honesty and ethics that forms the basis of auditors' job responsibilities and encourages auditors to behave ethically. 


\section{Literature Review and Hypothesis Development}

\subsection{Scepticism}

An auditor who has professional skepticism will not just accept the explanation from the client, but will ask questions to obtain reasons, evidence and confirmation regarding the object in question. Professional skepticism will lead auditors to take action to choose effective audit procedures in order to obtain the right audit opinion [6]. Auditor professional skepticism can be influenced by several factors, including expertise, experience, the audit situation at hand, and ethics [7]. Skepticism, derived from the word skeptic, in the Big Indonesian Dictionary means doubting, suspicious, and does not believe in the truth of a thing, theory, or statement. In the book accounting and auditing terms, skepticism means being hesitant about statements that are not sufficiently strong the basics of proof are [8]. Meanwhile, professionals, according to the Big Indonesian Dictionary, skepticism is something related to the profession, which requires special expertise to apply it.

The word professional in professional skepticism refers to the fact that auditors have been, and continue to be educated and trained to apply their expertise in making decisions according to professional standards [9]. Professional skepticism itself does not have a definite definition [10], but from the definition of the word skepticism and professionalism, it can be concluded that the auditor's professional skepticism is the attitude of auditors who always doubt and question everything, and critically assess audit evidence and make audit decisions based on his auditing skills. Skepticism does not mean not believing, but looking for proof before you can believe a statement [11].

Specifically in auditing, the Auditor Professional Standards [12] explain that professional skepticism is an attitude that always questions and evaluates audit evidence critically. A similar understanding is presented in the International Standards on Auditing [13], professional skepticism is an attitude that includes a questioning mind, alerts to conditions and circumstances that indicate the possibility of material misstatement caused by mistakes or intentions (fraud), and critical assessment (assessment) of audit evidence. The concept of professional skepticism reflected in these standards is an attitude of always asking questions, being alert, and critical in carrying out the entire audit process.

\subsection{Ethical Codes and Competencies}

This code of conduct contains standards of behavior as a guide for all internal auditors. These standards of behavior form the basic principles for carrying out internal audit practice. Internal auditors are obliged to carry out their professional responsibilities with wisdom, dignity and honor. In applying this auditor code of ethics, the internal auditor must pay attention to the prevailing laws and regulations.

The standards of behavior for internal auditors are as follows [14]:

a. Internal auditors must demonstrate honesty, objectivity and seriousness in carrying out their duties and fulfilling their professional responsibilities;

b. Internal auditors must show loyalty to the parties served. However, accordingly, the internal auditors must not knowingly engage in activities that deviate or violate the law;

c. Internal auditors must not be consciously involved in actions or activities that can discredit the internal audit profession; 
d. Auditors may not accept anything in any form from auditors, auditors, customers, suppliers, or from auditors, or can reasonably be suspected of affecting their professional judgment;

e. Internal auditors only perform services that can be completed using their professional competence;

f. Internal auditors must make every effort to meet the Professional Standards for Internal Audit;

g. Internal auditors must act prudently and wisely in using the information obtained in carrying out their duties. Internal auditors must not use confidential information to; (1) get personal benefits; (2) breaking the law; (3) cause harm to the auditee;

h. In reporting the results of their work, internal auditors must disclose all important facts that are known to them, because undisclosed facts can: (1) distort reports on the activities being reviewed, or (2) cover up any unlawful practices;

i. Internal auditors must constantly improve the competence and effectiveness and quality of their duties. Internal auditors are required to attend continuing professional education.

Regulation of the Minister of State for State Apparatus Empowerment No.PER / 04 / M.PAN / 03/2008 dated March 31, 2008 concerning the Ethics of Government Internal Supervisory Apparatus stated in the general standards of performance audits and investigative audits covering standards related to the principles must be obeyed by the auditor in carrying out their duties. The principles in question are integrity, objectivity, confidentiality and norms.

Competence is a set of intelligent actions full of responsibility that a person has as a condition to be considered capable by the community in carrying out tasks in a certain field of work [15]. It further explains that the level of competence can be seen from the following four points:

a. Ability to master knowledge and skills (Know how and know why)

b. Ability to work (know to do)

c. Ability to respond and behave in work, so that they have independence in assessing and making decisions responsibly

d. Ability to work together in social life with mutual respect and respect for the values of pluralism and peace (to live together)

Arnan et.al., [16] explained that there are four characteristics of competence, namely motive, innate, academic knowledge and expertise. A motive is something someone consistently thinks or wants that causes an action to appear. Motive will direct and select attitudes into actions or goals so that they are different from others. Congenital characteristics can be physical characteristics or habits in responding to certain situations or information. Knowledge is a complex competency. Scores on knowledge tests are often less useful for predicting a person's performance in the workplace because of the difficulty in measuring the need for knowledge and skill actually used on the job.

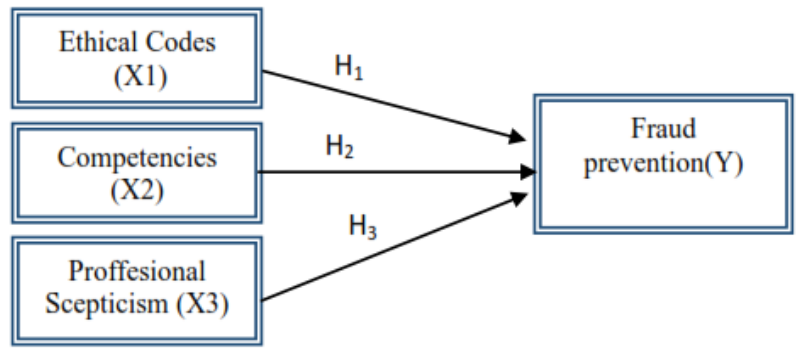

Fig. 1. The arrow image shows the inner hypothesis be tested in the study 
This line means whether the variable code of ethics, competence of professional skepticism affects fraud prevention.

H1: Ethical Codes has a positif relationship on fraud prevention.

$\mathrm{H} 2$ : Competencies has a positif relationship on fraud prevention.

H3: Proffesional Scepticism has a positif relationship on fraud prevention.

Multiple regression analysis is used for several influence variables $(\mathrm{X})$ on the dependent variable $(\mathrm{Y})$ with multiple linear models. In this study, multiple linear regression analysis was used to examine the effect of code of ethics (X1), competence (X2) and professional skepticism (X3) on fraud prevention $(\mathrm{Y})$. The multiple linear regression formula used in this study is as follows:

$\mathrm{Y}=\mathrm{a}+\mathrm{b}_{1} \mathrm{X}_{1}+\mathrm{b}_{2} \mathrm{X}_{2}+\mathrm{b}_{3} \mathrm{X}_{3}+\mathrm{e}$

Information:

Y : Fraud prevention.

a : Constanta

b1 : Coeffisien

b2 : Coeffisien

b3 : Coeffisien profesional

$\mathrm{X}_{1}$ : Ethical codes

$\mathrm{X}_{1}$ : Competencies

$\mathrm{X}_{1}$ : Proffesional Scepticism

e : Errorterm

\section{Methodology}

The type of research to be carried out is this research is classified as a causal research. Causal research is a type of research that is used to analyze the effect of one variable on another. [17]. This study states a casual associative relationship (cause-effect), that is, there are independent variables (variables that influence) and there are dependent variables (variables that are influenced). We operate survey method in order to obtain primary data. According to Husien [18] population is a generalization area that has certain characteristics and has the same opportunity to be selected as a sample member. According to Sugiyono [19], the sample is part of the number and characteristics of the population, while according to Husein [18] the sample is the smallest part of a population. The population and sample in this study were 134 auditors at the Inspectorate Office in Bengkulu Province.

\section{Result and Discussion}

The results of the regression analysis conducted on the effect of the code of ethics, competence and professional skepticism on fraud prevention are summarized in the Table 1. Multiple Regression Result.

\begin{tabular}{lccc}
\hline \multicolumn{1}{c}{ Variable } & $\begin{array}{c}\text { Beta } \\
(\text { Standardized })\end{array}$ & t & Sig \\
\hline Ethical Codes & 0,441 & 7,520 & 0,000 \\
\hline
\end{tabular}




\begin{tabular}{lccc}
\hline \multicolumn{1}{c}{ Variable } & $\begin{array}{c}\text { Beta } \\
\text { (Standardized) }\end{array}$ & $\mathbf{t}$ & Sig \\
\hline Competencies & 0,418 & 7,412 & 0,000 \\
Proffesional Scepticism & 0,611 & 13,486 & 0,000 \\
\hline Korelation (R) & 0,943 & & \\
Adjusted R ${ }^{2}$ & 0,886 & & \\
Fvalue & 311,397 & & \\
Sig. & 0,000 & & \\
Prob. & $0,05(5 \%)$ \\
\hline
\end{tabular}

Source: Processed Data

Based on the result of multiple regression analysis we proposed the equation as follows:

$\mathrm{Y}=0,441 \mathrm{X}_{1}+0,418 \mathrm{X}_{2}+0,611 \mathrm{X}_{3}$

The regression coefficient (beta) value of the code of ethics variable is 0.441 . These results indicate that the code of ethics has a positive effect on fraud prevention. This means that the higher the auditor in upholding the code of ethics, the auditor will have a high tendency to take fraud prevention measures. Furthermore, the regression coefficient value of the competency variable is 0.418 , which means that competence also has a positive effect on fraud prevention. This means that the higher the competence of the auditors in conducting the audit, the more likely the auditors will take action to prevent fraud.

The regression coefficient (beta) value of the professional skepticism variable is 0.611 . These results indicate that professional skepticism has a positive effect on fraud prevention. This means that the higher the professional skepticism the Inspectorate auditors have in Bengkulu Province, the auditors will have a high tendency to take fraud prevention measures.

\subsection{The Effect of the Code of Ethics on Fraud Prevention}

The results showed that the code of ethics had a positive and significant effect on fraud prevention. This means that if the auditor upholds the code of ethics, the auditor will have the responsibility to prevent fraud. Based on the descriptive analysis, it is known that the auditor's understanding of the code of ethics is in the very high category. This result means that the auditors have high independence, objectivity and integrity in carrying out their duties as government auditors. An auditor who has high idealism means that the auditor believes and believes that abusing his authority and being irresponsible in his duties has violated his professional ethics. Meanwhile, the form of low idealism means that the auditor does not have solid principles so that he tends to violate his professional ethics.

The audit code of ethics is the professional moral principles of auditors. The ethics includes principles of behavior for professionals designed for both practical and idealistic purposes. A professional code of ethics, among others, is designed to encourage ideal behavior, so a code of ethics must be realistic and enforceable. The development of ethical / moral awareness plays a key role in all areas of the accounting profession [20], including exercising the professional skepticism of auditors.

Based on the research results, it is known that the auditors at the Inspectorate Office of Bengkulu Province are idealistic auditors. An idealist auditor is an auditor who applies the principles of professional moral auditors well. These professional principles are behaviors for professionals designed for both practical and idealistic purposes. This is as stated by Louwers [21] which states that professional ethics is designed to encourage ideal, realistic and 
implementable behavior and to train auditors' professional skepticism, including auditors at the Inspectorate Office of Bengkulu Province.

In Kohlberg's theory of moral development in Fitriany [22] it is stated that moral reasoning is the basis of ethical behavior. This theory provides evidence that auditors must be able to comply with the rules, ethics and provisions that have been determined so that auditors become more objective. An objective auditor is an auditor who considers the audit evidence he obtains. The more objective an auditor is, the higher the level of professionalism will be.

An auditor cannot control behavior completely under control or does not return to the individual. If auditors have high moral and professional responsibilities, of course auditors are not easily weakened by the pressures exerted by certain parties. Auditors continue to carry out their duties in accordance with the provisions of the governing profession, including in the activities of regional financial supervision and control.

\subsection{The Effect of Competence on Fraud Prevention}

The results showed that the competency variable had a positive and significant effect on fraud prevention. This means that if auditors are increasingly competent in their field of work, auditors will carry out their duties responsibly and prevent fraud. The impact of the auditor's competence on fraud prevention is supported by the respondent's perception that the respondent is in the "knowing" category. These results indicate that the auditors at the Inspectorate of Bengkulu Province have an adequate level of knowledge because they are in the "knowing" category. The level of knowledge of auditors in carrying out is indicated by knowledge of established audit standards, knowledge of accounting to support the implementation of audits and certain technical knowledge, so that when conducting the audit can help. This knowledge plays an important role in carrying out audits according to established supervisory standards.

To further increase knowledge about auditing standards, the efforts made are necessary training on auditing standards and workshops that provide material on the implementation of supervision. By participating in these activities, auditors will gain additional knowledge, which is useful in carrying out their supervisory duties. The respondent's perceived value is in the 'good' category. These results indicate the auditors of the Inspectorate of Bengkulu Province have good behavior in conducting audits, so that they will produce a good audit report. The positive behavior shown by the auditor is fully responsible for the audit task and does not waste time. This also means that auditors have a good understanding of their duties and responsibilities as government auditors. To improve employee work attitudes, continuous guidance efforts are required for auditors. Efforts to provide guidance to auditors can be done by giving the auditors the opportunity to take higher education in the field of audit, so that after completing the education, auditors have adequate attitudes and competencies and can carry out audit tasks well.

\subsection{The Influence of Professional Skeptism on Fraud Prevention}

The results showed that professional skepticism had a positive effect on the prevention of auditor fraud. This means that professional skepticism will be able to increase auditors' desire to prevent fraud. High professional skepticism shows that auditors uphold professional ethics and code of ethics properly. These results indicate that the auditors of the Inspectorate of Bengkulu Province have understood the auditing standards, in which they are not rushing to provide a statement of audit results, without first analyzing the reports and sufficiently strong evidence. This condition means that the auditors have high professional skepticism. Therefore, 
to increase the professional skepticism of the auditors, additional time is needed in gathering audit evidence, so that the auditor can be careful and do not rush to provide an audit opinion. This is so that the results of the audit carried out have the desired quality level.

Being skeptical does not mean that the auditors do not have full confidence in the financial statements presented by regional financial reporting entities. This skepticism is aimed at testing and reviewing that the audited financial statements have been presented correctly, accurately, and accountably. Auditors use a skeptical attitude only to carry out their professional responsibilities, so that the results of the audit reports made are not wrong and not objective.

Based on the descriptive analysis, it is known that professional skepticism is in the very high category. This result means that in exercising their skepticism the auditors at the Inspectorate Office in Bengkulu Province are very careful before taking any action to prevent fraud. The auditor's caution is such as not hastily providing the results of audit evaluation before they are supported by accurate evidence, matching reports with sufficient evidence and applicable regulations. The auditors are careful to do this so that no party will be harmed by the results of the examination that will be given later.

When viewed from the demographic characteristics possessed by respondents, it shows that from the age of the respondents on average they are mature and mature. In addition, a good level of education makes respondents have broad thoughts, so that they have maturity in their thoughts in taking a stand to take fraud prevention. This is because his actions could pose a risk to him personally, but because it is a professional responsibility, the auditors have the courage to do so.

Professional auditors of course always adhere to the code of ethics of their profession. Professional code of ethics must be implemented because it is an obligation of the auditor. The auditor's code of ethics will guide the auditors to carry out their duties properly, neutrally, accountably and professionally. If during the supervision and examination, an irregularity is found, this will be accompanied by submitting questions to obtain reasons, evidence and confirmation of the irregularities in question (Noviyanti, 2008).

Auditor's professional skepticism is an attitude that includes the mind that always questions and evaluates the audit evidence skeptically. Auditors are required to exercise their professional skepticism so that auditors can use their professional skills carefully and thoroughly, because the professional skills of an auditor affect the opinion they give. The objective of the auditor to obtain sufficient evidence of competence and to provide an adequate basis for formulating an opinion can be achieved properly. In the implementation of the practice of auditing services, some people still have doubts about the level of professional skepticism held by auditors which in turn have an impact on public doubts about giving opinions.

In the APIP Auditor Behavior Standards (SPA) (2007) it is explained that an auditor must show honesty, objectivity and seriousness in carrying out his duties and fulfilling his professional responsibilities. The auditors at the Inspectorate Office in Bengkulu Province must also comply with the norms stipulated in the Auditor's Standards of Conduct. Inspectorate Office auditors must also be careful and prudent in using the information obtained in carrying out their duties.

\section{Conclussion}


The objectives of the research is to test the effect of professional and ethical skepticism on fraud prevention at the Inspectorate Office in Bengkulu Province. Based on the results of data analysis and hypothesis testing, it can be concluded that:

a. The code of ethics has a positive effect on the prevention of auditor fraud. This means that the higher the auditor upholds the code of ethics, the higher the tendency for auditors to take fraud prevention measures.

b. Competence has a positive effect on the prevention of auditor fraud. This means that the more competent auditors are in their field of work, the auditors have a high tendency to take fraud prevention measures.

c. Professional skepticism has a positive effect on the prevention of auditor fraud. This means that the higher the professional skepticism of the auditors, the more likely the auditors are to take fraud prevention measures.

\section{References}

[1] Peraturan Menteri Negara Pendayagunaan Aparatur Negara (Permenpan) Nomor: 19 Tahun 2009 tentang pedoman kendali mutu audit aparat pengawasan intern pemerintah.

[2] Rahmawati dan Idjang. Analisis Pengaruh Pengalaman Akuntan pada Pengetahuan dan Penggunaan Intuisi dalam Mendeteksi Kekeliruan. Jurnal Riset Akuntansi Indonesia Vol.2 No. 2 Juli, hlm. 154-172, 2012.

[3] Kumaat. Whistleblowing dalam Skandal Enron dan Wordlcom: Perlawanan Individu Terhadap Sistem. Jurnal Sekolah TInggi Akuntansi, Vol. 4 No. 4 hal. 99-129, 2001.

[4] Arens, Alvins A. dan James K. Loebbecke. Auditing: Suatu Pendekatan Terpadu (judul asli: Auditing, An Integrated Approach). Penerjemah Ilham Tjakrakusuma. Jakarta: Erlangga, 2008.

[5] Arrens, A. Auditing dan Pelayanan Verifikasi: Pendekatan Terpadu. Jakarta: Tim Dejacarta, 2008.

[6] Novianti, Suzy. Skeptisme Profesional Auditor dalam Mendeteksi Kecurangan. Universitas Setya Kencana, 2008.

[7] Gusti, Maghfirah dan Syahril Ali. Hubungan Skeptisisme Profesional Auditor Dan Situasi Audit, Etika, Pengalaman Serta Keahlian Audit Dengan Ketepatan Pemberian Opini Auditor Oleh Auditor. Universitas Andalas. Padang, 2008.

[8] Islahuzzaman. Istilah-Istilah Akuntansi dan Auditing. Bumi Aksara, 2012.

[9] Quadackers. A study of auditors' skeptical characteristics and their relationship to skeptical judgments and decisions, 2009. http://hdl.handle.net/1871/13280

[10] Louwers, dkk. Sample Sizes when using Multiple Linear Regression for Prediction. New York: Educational and Psychological Department, 2008.

[11] IAI, 2015. Standar Profesional Akuntan Publik Indonesia, Salemba Empat, Jakarta.

[12] IAASB, 2009. International Accounting and Audit Standard Board, USA.

[13] BPKP, 2007. Kode Etik dan Standar Audit. Pusdiklatwas BPKP Edisi 5 Center for Audit Quality, 2010.

[14] Peraturan Menteri Negara Pendayagunaan Aparatur Negara (Permenpan) Nomor:Per/05/M.Pan/03/2008 tentang Standar Audit Aparat Pengawasan Intern Pemerintah. LAN-Jakarta.

[15] Arnan, S. G., N. Wisna, dan I. Firmansyah. 2009. “Auditing.” Bandung: Politeknik Telkom. 
[16] Husein, Umar. Metode Penelitian Untuk Skripsi dan Tesis Bisnis. Jakarta: Rajawali Pers, 2009.

[17] Sekaran, Uma. Research Methods for Business: Metodologi Penelitian untuk Bisnis (Edisi 4). Jakarta. Salemba Empat, 2006.

[18] Sugiyono, Metode Penelitian Bisnis, Edisi Kesepuluh, Alfabeta, Bandung, 2011.

[19] Louwers, The Effects of Moral Intensity on Whistleblowing Behaviour Accounting Professional, Journal of Forensic and Investigate Accounting, Vol. 3 No., hal. 34-56, 2011.

[20] Louwers, Sanne. Long Island University, Brooklyn Campus. Brooklyn, New York, 2011.

[21] Fitriani, Riska, dkk. The Moral Development Of The Main Character Sebastian Wilder Portrayed In La La Land Movie (2016) Ilmu Budaya: Jurnal Bahasa, Sastra, Seni dan Budaya Vol 3, No 1 (2019): Januari 2019.

[22] APIP Auditor Behavior Standards (SPA) (2007). 